\title{
MUlTIPLE RESISTANCE OF Amaranthus palmeri TO ALS AND EPSPS Inhibiting HeRbicides in the State of Mato Grosso, BRaziL ${ }^{1}$
}

\author{
Resistência Múltipla de Amaranthus palmeri aos Herbicidas Inibidores da ALS e EPSPS no \\ Estado do Mato Grosso, Brasil
}

\author{
GONÇALVES NETTO, A. ${ }^{2}$, NICOLAI, M. ${ }^{3}$, CARVALHO, S.J.P. ${ }^{4}$, BORGATO, E.A. ${ }^{2}$, and \\ CHRISTOFFOLETI, P.J. ${ }^{2}$
}

\begin{abstract}
This work was carried out in order to evaluate the susceptibility to ALS-inhibiting herbicides of the Brazilian biotype of glyphosate-resistant A. palmeri, considering different chemical groups. For that, four experiments were performed, each with one of the following herbicides: glyphosate, chlorimuron-ethyl, cloransulan-methyl and imazethapyr. In each trial, treatments were organized according to a $2 \times 8$ factorial scheme, in which two were the species of Amaranthus (A. palmeri and A. spinosus) and eight were the herbicide rates (16D, 8D, 4D, 2D, D, 1/2D, 1/4D and herbicide absence; being $\mathrm{D}$ the commercial rate of each product). For glyphosate, $\mathrm{D}=720 \mathrm{~g}$ a.e. $\mathrm{ha}^{-1}$; for chlorimuron-ethyl, $\mathrm{D}=20 \mathrm{~g} \mathrm{ha}^{-1}$; for cloransulanmethyl, D = $30 \mathrm{~g} \mathrm{ha}^{-1}$; for imazethapyr, D = $100 \mathrm{~g} \mathrm{ha}^{-1}$. Glyphosate was not applied on A. spinosus. In all the trials, the Brazilian biotype of $A$. palmeri had low herbicide susceptibility, so it was possible to conclude this biotype has ALS-EPSPs multiple resistance. Therefore, considering only ALS-inhibiting herbicides, this population has sulfonilurea-triazolopirimidineimidazolinone cross-resistance.
\end{abstract}

Keywords: Palmer amaranth, dose-response, management, control.

\begin{abstract}
RESUMO - Este trabalho foi desenvolvido com o objetivo de avaliar a suscetibilidade do biótipo brasileiro de A. palmeri, resistente ao herbicida glyphosate, a herbicidas inibidores da ALS de diferentes grupos quimicos. Para isso, quatro experimentos foram realizados, um com cada um dos seguintes herbicidas: glyphosate, chlorimuron-ethyl, cloransulan-methyl e imazethapyr. Em cada experimento, os tratamentos foram organizados em esquema fatorial $2 x 8$, em que duas foram as espécies de Amaranthus (A. palmeri e A. spinosus) e oito foram as doses de herbicida (16D, $8 D, 2 D, 4 D, D, 1 / 2 D, 1 / 4 D$ e ausência do herbicida, sendo $D$ a dose comercial recomendada de cada produto). Para glyphosate, $D=720 \mathrm{~g}$ e.a. ha $\mathrm{h}^{-1}$; para chlorimuron-ethyl, $D=20 \mathrm{~g}$ ha ${ }^{-1}$; para cloransulan-methyl, $D=30 \mathrm{~g} \mathrm{ha}^{-1}$; e para imazethapyr, $D=100 \mathrm{~g} \mathrm{ha}^{-1}$. Não foi aplicado glyphosate sobre A. spinosus. Em todos os experimentos, os biótipos de A. palmeri tiveram baixa suscetibilidade aos herbicidas, de modo que se pôde concluir tratar-se de um caso de resistência múltipla aos inibidores da EPSPs e ALS. Ainda, considerando somente os inibidores da ALS, conclui-se que o biótipo possui resistência cruzada às sulfonilureias - triazolopirimidinas imidazolinonas.
\end{abstract}

Palavras-chave: caruru-palmeri, dose-resposta, manejo, controle.

\section{INTRODUCTION}

Among weeds more commonly found in agriculture the ones classified as Amaranthus (pigweeds) genus are those that stand out, represented by around 60 species, and approximately 20 from those are important as weeds (Kissmann and Groth, 1999). In Brazil, there are around 10 species of this genus with agricultural importance, the

Recebido para publicação em 7.2.2016 e aprovado em 14.3.2016.

2 Escola Superior de Agricultura “Luiz de Queiroz", ESALQ/USP, Piracicaba - SP, Brasil, <acaciogn@agronomo.eng.br>; ${ }^{3}$ Agrocon Assessoria Agronômica - Santa Bárbara d'Oeste - SP, Brasil; ${ }^{4}$ Instituto Federal do Sul de Minas Gerais, IFSULDEMINAS, Machado - MG, Brasil. 
following standing out: A. deflexus, $A$. hybridus, A. lividus, $A$. retroflexus, $A$. spinosus and $A$. viridis (Carvalho et al., 2008).

The Brazilian Amaranthus species have annual life cycle, reproduce exclusively by seeds and, generally, are difficult to visually differentiate among the species, especially as seedlings. In the agricultural areas, they can be considered as difficult management plants due to the extended emergency period, to the fast growth and long viability of their seed bank (Horak and Loughin, 2000). Yet, a large sized plant can produce more than 200,000 seeds (Kissmann and Groth, 1999; Lorenzi, 2000). They compete with the agricultural crops for water, light and nutrients; reduce the amount and quality of the harvested product; and, especially the large-sized species, interfere in the harvest procedures (Klingaman and Oliver, 1994; Knezevic et al., 1997; Rowland et al., 1999; Carvalho and Christoffoleti, 2008).

However, recently, Andrade Junior et al. (2015) identified Palmer amaranth (A. palmeri) for the first time in Brazil, in the cotton northcentral region of the state of Mato Grosso, in areas where cotton, soybeans and corn are grown in rotation. Palmer amaranth comes from the arid regions of the South-Central of the United States of America (USA) and the north of Mexico, appearing in several countries. In recent years, this species has become the main weed in cotton areas in the USA, due to its biologic characteristics and resistance to herbicides of different action mechanisms (Ward et al., 2013).

Palmer amaranth is dioecious, which means that, in a population, part of the plants will only have female flowers ("female" plants) and the other part will only have male flowers ("male" plants), where seeds will only be produced by female flowers (Ward et al., 2013). This characteristic enables the identification of A. palmeri in the field, once the other species of amaranth that are important for Brazilian agriculture have male and female flowers in the same plant, being classified as monoecious.

In a paper done to verify susceptibility of A. palmeri to glyphosate in Brazil, the same population that was also used in the present paper, Carvalho et al. (2015) saw that this is a glyphosate resistant population and it demands dosages above 4,500 g a.e. $\mathrm{ha}^{-1}$ in order to reach $\mathrm{DL}_{80}$, which are economically and environmentally unfeasible.

In the USA, in addition to glyphosate, there are reports of Palmer amaranth populations resistant to other action mechanisms, such as ALS inhibitors, HPPD inhibitors, tubulin synthesis inhibitors (mitosis) and photosystem II inhibitors (FSII). The management of these populations becomes even more complex, especially for the populations with multiple resistance, which has been reported for two or three of these action mechanisms: ALS/ glyphosate, ALS/glyphosate/FSII and ALS/ FSII/HPPD (Beckie and Tardif, 2012; Ward et al., 2013; Heap, 2016). Besides the USA borders, there have been reports of $A$. palmeri resistant to ALS inhibitors in Israel (Heap, 2016) and EPSPs inhibitors in Argentina (Morichetti, 2013).

The ALS inhibitor herbicides can be used in pre-emergence or post-emergence in the control of glyphosate-resistant weeds in Brazil (Nicolai et al., 2008). Likewise, herbicides with this action mechanism have been used successfully in the control of A. palmeri resistant to glyphosate in the USA (Wise et al., 2009; Mohseni-Moghadam et al., 2013), which could possibly be an alternative to the control of resistant A. palmeri in Brazil.

Therefore, this work was developed with the objective of assessing the susceptibility of the Brazilian biotype of $A$. palmeri, considered resistant to glyphosate, to ALS inhibiting herbicides from different chemical groups.

\section{MATERIAL AND METHODS}

Four experiments were developed in a greenhouse of the Department of Crop Production at ESALQ/USP, in the city of Piracicaba, São Paulo (2242’S; 47³7’W; 545 m in altitude), between August and November 2015. Simultaneously, two populations of amaranth were evaluated, one of $A$. palmeri and one of $A$. spinosus (susceptible). The seeds of $A$. palmeri were the same that were used in the research developed by Carvalho et al. (2015); therefore, this population is proven to be resistant to glyphosate, while the seeds of A. spinosus were collected in the state of Mato Grosso. 
For the installation of the experiments, seeds were distributed in excess in rectangular plastic boxes, with capacity for $2.0 \mathrm{~L}$ of commercial substrate (peel of Pinus, peat and vermiculite) and vermiculite $(3: 1 ; \mathrm{v}: \mathrm{v})$. In the vegetative development stage of completely expanded cotyledons, that is, stage 10 (Hess et al., 1997), seedlings were transplanted into plastic pots with capacity for $1.0 \mathrm{~L}$. filled with the same substrate mixture, where they remained until the end of the experiment, in an average density of three plants per pot.

The susceptibility of the populations was quantified by dose response curves. All the experiments were installed in an experimental design of randomized blocks with five replicates. For each herbicide studied (Table 1), treatments were organized in a $2 \times 8$ factorial design, in which two were the species of Amaranthus (A. palmeri and A. spinosus) and eight were the herbicide doses, namely: 16D, 8D, 4D, 2D, D, 1/2D, 1/4D and absence of herbicide, $\mathrm{D}$ being the maximum commercial dose indicated on the label of each product (Table 1). Glyphosate was not applied on A. spinosus.

The sprays were done on plants in the stage from 3 to 4 pairs of leaves. For that, a $\mathrm{CO}_{2}$ pressurized precision backpack sprayer was used, coupled in a TeeJet 110.02 two-tip bar, positioned at $0.50 \mathrm{~m}$ from the target, with a spray relative consumption of $200 \mathrm{~L} \mathrm{ha}^{-1}$.

At 28 days after application (DAA), the percentage control was evaluated, as well as the residual dry matter of the plots. The control was analyzed by using a variable percentage scale between zero and 100, in which zero was attributed to the absence of symptoms caused by the herbicide and $100 \%$ to the death of the plants. Plant dry mass was obtained from the collection of the plant material remaining in the plots, with later drying in an oven at $70^{\circ} \mathrm{C}$ for 72 hours. Dry matter was corrected for the percentage values through the comparison of mass obtained in herbicide treatments with the mass of the check plots, considered 100\%.

Data analysis was performed through the application of the $F$ test in the variance analysis. The control variable was adjusted to the logistic model proposed by Streibig (1988):

$$
y=\frac{a}{\left[1+\left(\frac{x}{b}\right)^{c}\right]}
$$

where: $y=$ control percentage; $x=$ herbicide dosage; and $a, b$ and $c=$ curve parameters, so that $a$ is the difference between the maximum and minimum point of the curve, $b$ is the dosage that provides $50 \%$ of variable response and $c$ is the slope of the curve.

For the residual dry matter, the model adopted was the one proposed by Seefeldt et al. (1995):

$$
y=a+\frac{b}{\left[1+\left(\frac{x}{c}\right)^{d}\right]}
$$

where: $y=$ mass quantification; $x=$ herbicide dosage; and $a, b$ and $c=$ curve parameters, so that $a$ is the inferior limit of the curve, $b$ is the difference between the maximum and minimum point of the curve, $c$ is the dosage that provides $50 \%$ of variable response and $d$ is the slope of the curve.

The logistic model has advantages, once one of the terms of the equation ( $b$ or $c$ ) is an estimate of the $\mathrm{DL}_{50}$ or $\mathrm{GR}_{50}$ value (ChristoffoletI, 2002). $\mathrm{DL}_{50}$ (lethal dosage for

\begin{tabular}{|c|c|c|c|}
\hline Herbicide & Commercial name & ${ }^{1 /}$ Trade dosage $\left(\mathrm{g}\right.$ or $\left.\mathrm{L} \mathrm{ha}^{-1}\right)$ & g a.i. ha ${ }^{-1}$ \\
\hline Glyphosate & Roundup $^{(\mathbb{B}}$ & 2.0 & 720 \\
\hline Chlorimuron-ethyl & Classic $^{\circledR}$ & 80.0 & 20 \\
\hline Cloransulan-methyl & Pacto $^{(\mathbb{B}}$ & 35.7 & 30 \\
\hline Imazethapyr & Pivot $^{(\mathbb{R}}$ & 1.0 & 100 \\
\hline
\end{tabular}

Table 1 - Herbicides and dosages used in the experiments. Piracicaba /SP, 2015

1/ Rodrigues and Almeida (2011). 
$50 \%$ of the population) and $\mathrm{GR}_{50}$ (growth reduction by $50 \%$ ) are the dosages of herbicides that provide $50 \%$ of control or reduction of the weed mass, respectively (Christoffoleti, 2002; Christoffoleti and López-Ovejero, 2004). Although one of the parameters of the logistic model is an estimate of $\mathrm{DL}_{50}$, its mathematical calculation was also made through an inverse equation, according to the discussion proposed by Carvalho et al. (2005).

\section{RESULTS AND DISCUSSION}

Low sensitivity was detected in the biotype of Amaranthus palmeri to all the herbicides assessed. In some cases, it was not possible to discriminate the necessary doses to obtain $50 \%$ of control or reduction of the dry matter. This difficulty was even more frequent for the obtaining of doses of $80 \%$ control or reduction of dry matter (Table 2).

This Palmer amaranth population is known to be resistant to glyphosate (Carvalho et al., 2015), which was proven again in this paper. Considering the percentage control or dry matter, an average dosage of $8,500 \mathrm{~g} \mathrm{ha}^{-1}$ of glyphosate was necessary to obtain $\mathrm{DL}_{50}$ or $\mathrm{GR}_{50}$. It was not possible to estimate the necessary dosage to obtain $\mathrm{DL}_{80}$ or $\mathrm{GR}_{80}$, seeing that the demand was superior to the higher dosage used in the experiment (Table 2; Figure 1), that is, above 11,520 g a.e. ha ${ }^{-1}$.

These values corroborate the report of resistance in the population to glyphosate and justify the need to evaluate alternative herbicides for the control of this species, such as ALS inhibitors. Worldwide, there are currently 50 reported cases of $A$. palmeri resistant to herbicides, of several action mechanisms, including cases of multiple resistance involving EPSPs-ALS inhibiting herbicides (Heap, 2016).

Low herbicide sensitivity of $A$. palmeri was evident for ALS inhibitors as well, especially after comparing with the species $A$. spinosus, which had very high susceptibility and validated the sprays properly (Table 2 ). In the case of chlorimuron-ethyl, for instance,

Table 2 - Variables assessed (percentage control at $28 \mathrm{DAA}^{\stackrel{1}{1}}$ or dry matter), parameters of the logistic model ${ }^{2 /}$, determination coefficient $\left(\mathrm{R}^{2}\right)$ and lethal dosage (DL) or growth reduction (GR) for the susceptibility of Amaranthus populations to different herbicides. Piracicaba/SP, 2015

\begin{tabular}{|c|c|c|c|c|c|c|c|c|}
\hline \multirow{2}{*}{ Species } & \multirow{2}{*}{ Variable } & \multicolumn{4}{|c|}{ Parameters } & \multirow{2}{*}{$\mathrm{R}^{2}$} & \multicolumn{2}{|c|}{ DL or GR } \\
\hline & & Pmin & $\mathrm{a}$ & $\mathrm{b}$ & $\mathrm{c}$ & & 50 & 80 \\
\hline \multicolumn{9}{|c|}{ Glyphosate } \\
\hline \multirow{2}{*}{ A. palmeri } & $28 \mathrm{DAA}$ & --- & 107.769 & 9301.508 & -1.428 & 0.977 & 8406.76 & $>11,520$ \\
\hline & Dry Matter & 12.353 & 76.048 & 8538.133 & 4.042 & 0.941 & 8580.12 & $>11,520$ \\
\hline \multicolumn{9}{|c|}{ Chlorimuron-ethyl } \\
\hline \multirow{2}{*}{ A. palmeri } & $28 \mathrm{DAA}$ & --- & 108.694 & 214.342 & -1.022 & 0.991 & 183.22 & $>320$ \\
\hline & Dry Matter & -6.347 & 105.855 & 189.195 & 0.542 & 0.912 & 232.08 & $>320$ \\
\hline \multirow{2}{*}{ A. spinosus } & $28 \mathrm{DAA}$ & --- & 98.422 & 1.674 & -1.101 & 0.977 & 1.72 & 6.35 \\
\hline & Dry Matter & 5.491 & 94.583 & 4.313 & 0.831 & 9.950 & 4.97 & 33.69 \\
\hline \multicolumn{9}{|c|}{ Cloransulan-methyl } \\
\hline \multirow{2}{*}{ A. palmeri } & 28 DAA & --- & 179.262 & 5445.886 & -0.486 & 0.958 & $>480$ & $>480$ \\
\hline & Dry Matter & 10.672 & 66.253 & 906.970 & 3.066 & 0.891 & $>480$ & $>480$ \\
\hline \multirow{2}{*}{ A. spinosus } & 28 DAA & --- & 94.701 & 1.942 & -1.381 & 0.986 & 2.11 & 6.62 \\
\hline & Dry Matter & -0.671 & 101.419 & 4.310 & 0.302 & 0.882 & 4.33 & $<7.5$ \\
\hline \multicolumn{9}{|c|}{ Imazethapyr } \\
\hline \multirow{2}{*}{ A. palmeri } & $28 \mathrm{DAA}$ & --- & 123.272 & 1716.888 & -0.669 & 0.983 & 969.75 & $>1,600$ \\
\hline & Dry Matter & 1.159 & 87.019 & 1787.977 & 1.048 & 0.927 & $1,342.13$ & $>1,600$ \\
\hline \multirow{2}{*}{ A. spinosus } & $28 \mathrm{DAA}$ & --- & 100.157 & 11.069 & -1.957 & 0.985 & 11.05 & 22.39 \\
\hline & Dry Matter & 14.848 & 85.637 & 10.920 & 1.386 & 0.975 & 14.18 & 79.34 \\
\hline
\end{tabular}

1/DAA - days after application; ;/ $\mathrm{y}=\mathrm{a} /\left(1+(\mathrm{x} / \mathrm{b})^{\mathrm{c}}\right)$ or $\mathrm{y}=\mathrm{a}+\mathrm{b} /\left(1+(\mathrm{x} / \mathrm{c})^{\mathrm{d}}\right)$. 

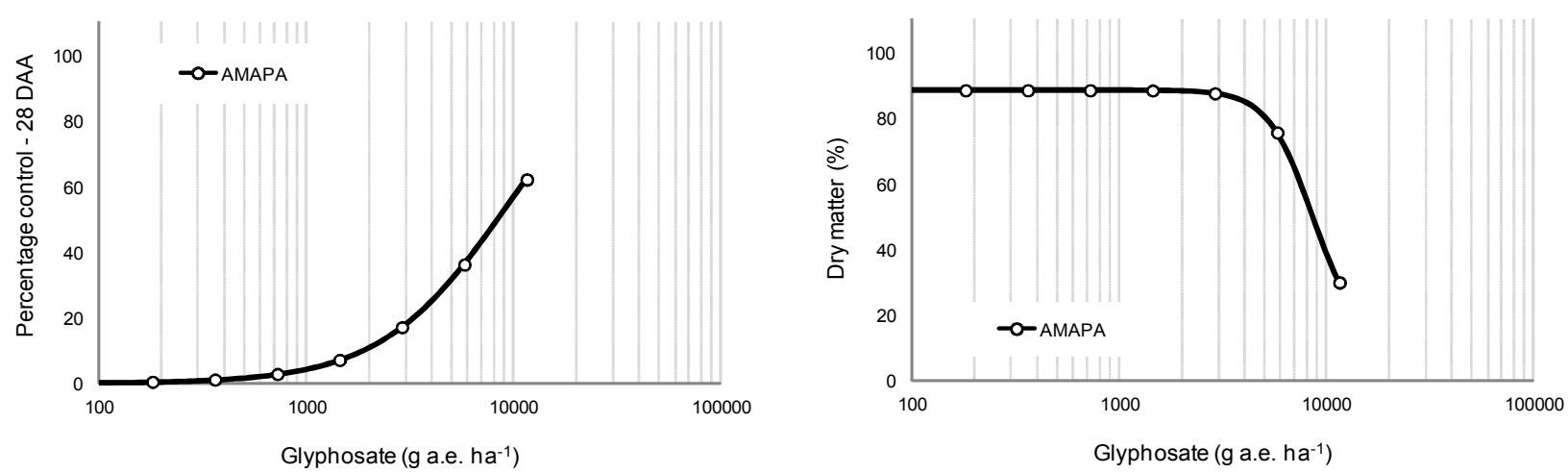

Figure 1 - Percentage control and dry matter of Amaranthus palmeri (AMAPA) subjected to different dosages of glyphosate, assessed at 28 days after application (DAA). Piracicaba /SP, 2015.

less than $10 \mathrm{~g} \mathrm{ha}^{-1}$ was enough to control A. spinosus above $80 \%$. However, in the case of A. palmeri, it was not possible to estimate $\mathrm{DL}_{80}$ or $\mathrm{GR}_{80}$, seeing that the demanded rate was above $320 \mathrm{~g} \mathrm{ha}^{-1}$ of chlorimuron, that is, $A$. spinosus has high sensitivity to the molecule, while A. palmeri is insensitive to the same herbicide, considering commercial doses and the same spraying conditions (Table 2; Figure 2).

Wise et al. (2009), in a study done with populations of $A$. palmeri from 30 different locations of the state of Georgia (USA), obtained satisfactory control when they used $13 \mathrm{~g} \mathrm{ha}^{-1}$ of this herbicide (chlorimuron-ethyl), reaching mass reduction of $64 \%$ in relation to the check plots without treatment.

As for the Brazilian biotypes of Amaranthus, the same response pattern observed for chlorimuron was kept for cloransulanmethyl and imazethapyr, considering high susceptibility of $A$. spinosus and very low sensitivity of $A$. palmeri (Figures 3 and 4). In a previous report, Andrade Júnior et al. (2015) made comments on the low sensitivity of the A. palmeri population to glyphosate and also to ALS inhibitors. These authors already considered the possibility of multiple resistance to glyphosate - ALS, but that still needed scientific proof.

The species $A$. palmeri and $A$. spinosus share a common ancestral, more than other species of amaranth, seeing that they have the same number of chromosomes $(2 n=34)$, pollen grain morphological similarities (Franssen et al., 2001) and similarities in the genome size (Rayburn et al., 2005). Moreover, A. palmeri and $A$. spinosus were classified as sisters by the analysis of the phylogenetic rate, once all the other studied rates for other species of Amaranthus were excluded, which indicates that other species of amaranth are more distant from A. palmeri and A. spinosus (Wassom and Tranel, 2005; Riggins et al., 2010).

In the evaluation of the different ALS inhibitor herbicides belonging to three different chemical groups - sulphonylurea (chlorimuron-ethyl), triazolopyrimidine (cloransulan-methyl) and imidazolinone (imazethapyr) - , none of the herbicides evaluated was able to appropriately control the population of $A$. palmeri. It was not possible, at least, to estimate $\mathrm{DL}_{80}$ or $\mathrm{GR}_{80}$ even using doses 16 times higher than the ones commercially recommended of the products (Rodrigues and Almeida, 2011), showing the insensitivity to the molecules (Table 2; Figures 2, 3 and 4).

In Brazil, until now, a biotype of $A$. palmeri susceptible to glyphosate or ALS inhibitors has not been identified in order to enable scientific comparison of the $\mathrm{DL}_{50}$ and $\mathrm{GR}_{50}$ values. However, from the values identified on Table 2 , it is possible to affirm that it is a population with multiple resistance to EPSPs and ALS inhibitors. Also, considering only the ALS inhibiting herbicides, this population has cross-resistance among sulfonylureas triazolopyrimidines - imidazolinones.

In that sense, recommendations of herbicides based on EPSPs and ALS inhibitors should be avoided for the control of $A$. palmeri 

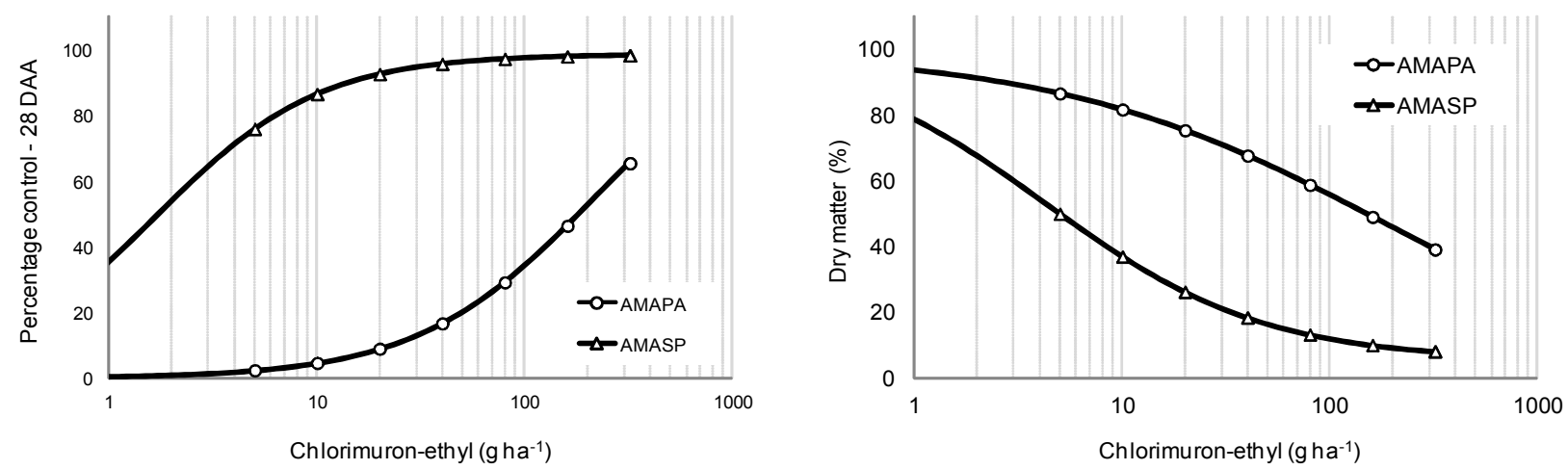

Figure 2 - Percentage control and dry matter of Amaranthus palmeri (AMAPA) and A. spinosus (AMASP) subjected to different dosages of chlorimuron-ethyl, assessed at 28 days after application (DAA). Piracicaba /SP, 2015,
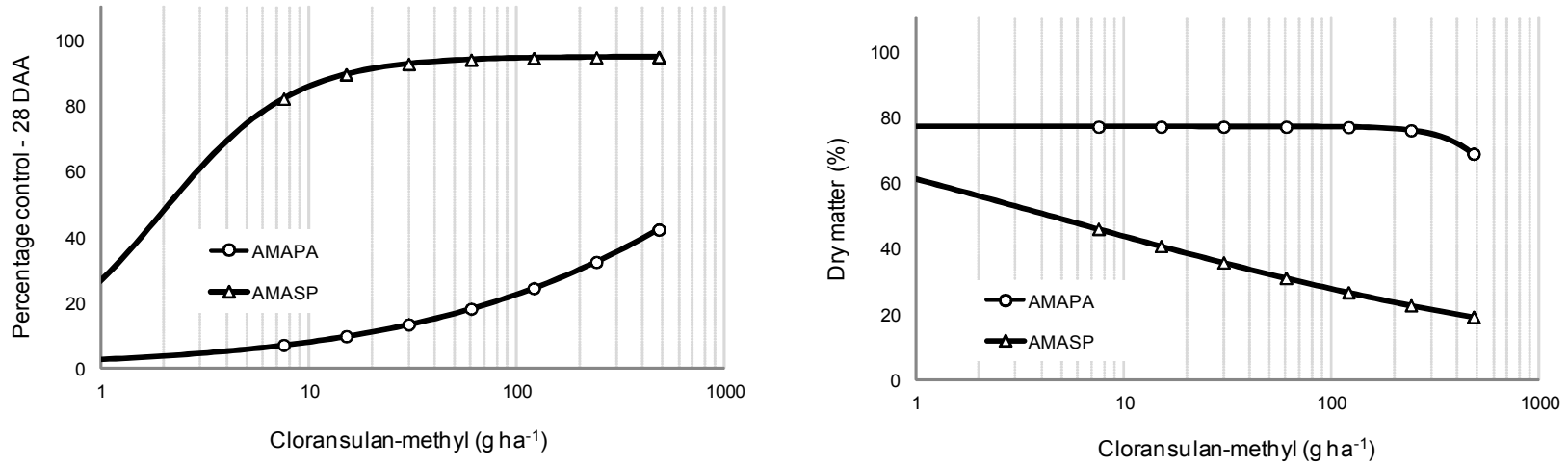

Figure 3 - Percentage control and dry matter of Amaranthus palmeri (AMAPA) and A. spinosus (AMASP) subjected to different dosages of cloransulan-methyl, assessed at 28 days after application (DAA). Piracicaba /SP, 2015,
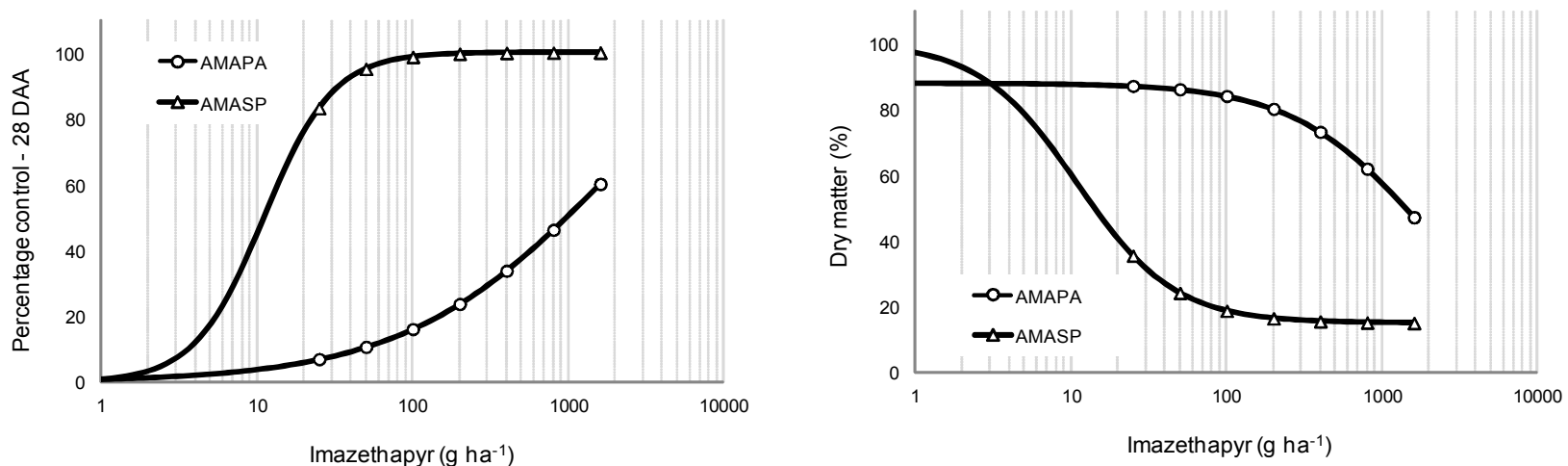

Figure 4 - Percentage control and dry matter of Amaranthus palmeri (AMAPA) and A. spinosus (AMASP) subjected to different dosages of imazethapyr, assessed at 28 days after application (DAA). Piracicaba /SP, 2015.

identified in areas of Mato Grosso. Therefore, new management alternatives must be evaluated, including photosystems I and
II inhibitors, auxin-mimetic herbicides, PROTOX inhibitors and carotenoid synthesis inhibitors. 


\section{ACKNOWLEDGEMENTS}

The authors wish to thank the Coordenação de Aperfeiçoamento de Pessoal de Nivel Superior (CAPES) for the scholarship granted to the first author.

\section{REFERENCES}

Andrade Júnior E.R. et al. Primeiro relato de Amaranthus palmeri no Brasil em áreas agrícolas no estado de Mato Grosso. Circular Técnica IMA-MT. 2015;19:1-8.

Beckie H., Tardif F.J. Herbicide cross resistance in weeds. Crop Protec. 2012;35:15-28.

Carvalho S.J.P. et al. Crescimento e desenvolvimento de cinco espécies de plantas daninhas do gênero Amaranthus. Bragantia. 2008;67:317-26.

Carvalho S.J.P. et al. Curvas de dose-resposta para avaliação do controle de fluxos de emergência de plantas daninhas pelo herbicida imazapic. Planta Daninha. 2005;23:535-42.

Carvalho S.J.P. et al. Detection of glyphosate-resistant palmer amaranth (Amaranthus palmeri) in agricultural areas of Mato Grosso, Brazil. Planta Daninha. 2015;33:579-86.

Carvalho S.J.P., Christoffoleti P.J. Competition of Amaranthus species with dry bean plants. Sci Agric. 2008;65:239-45.

Christoffoleti P.J. Curvas de dose-resposta de biótipos resistente e suscetível de Bidens pilosa L. aos herbicidas inibidores da ALS. Sci Agric. 2002;59:513-9.

Christoffoleti P.J., López-Ovejero R.F. Definições e situação da resistência de plantas daninhas aos herbicidas no Brasil e no Mundo. In: Christoffoleti P.J., coordenador. Aspectos de resistência de plantas daninhas a herbicidas. $3^{\mathrm{a}}$. ed. Campinas: Associação Brasileira de Ação a Resistência de Plantas aos Herbicidas (HRAC-BR), 2008. p.3-22.

Franssen A.S. et al. Pollen morphological differences in Amaranthus species and interspecific hybrids. Weed Sci. 2001;49:732-7.

Heap I. The international survey of herbicide resistant weeds. [accessed on: 17 Jan. 2016]. Available at: http:// www.weedscience.org.

Hess, M. et al. Use of the extended BBCH scale - general for descriptions of the growth stages of mono-and dicotyledonous weed species. Weed Res. 1997;37:433-41.

Horak M.J., Loughin T.M. Growth analysis of four Amaranthus species. Weed Sci. 2000;48:347-55.

Kissmann K.G., Groth, D. Plantas infestantes e nocivas. 2nd. ed. São Paulo: BASF, 1999. 978p.
Klingaman T.E., Oliver L.R. Palmer amaranth (Amaranthus palmeri) interference in soybeans (Glycine max). Weed Sci. 1994:42:523-7.

Knezevic S.Z. et al. Relative time of redroot pigweed (Amaranthus retroflexus) emergence is critical in pigweedsorghum [Sorghum bicolor (L.) Moench] competition. Weed Sci. $1997 ; 45: 502-8$.

Lorenzi H. Plantas daninhas do Brasil: terrestres, aquáticas, parasitas e tóxicas. $3^{\text {a }}$.ed. Nova Odessa: Instituto Plantarum, 2000. 608p

Mohseni-Moghadam M. et al. Resistance to glyphosate in Palmer amaranth (Amaranthus palmeri) populations from New Mexico pecan orchards. Weed Technol. 2013;27:85-91.

Morichetti S. et al. Sobre la presencia de Amaranthus palmeri (Amaranthaceae) en Argentina. B Soc Argentina Bot. 2013;48:347-54.

Nicolai M. et al. Resistência de plantas daninhas aos herbicidas inibidores da ALS (Grupo B). In: Christoffoleti P.J., coordenador Aspectos de resistência de plantas daninhas a herbicidas. $3^{\mathrm{a}}$. ed. Campinas: Associação Brasileira de Ação a resistência de Plantas aos Herbicidas (HRAC-BR), 2008. p.3-22.

Rayburn A.L. et al. Genome size analysis of weedy Amaranthus species. Crop Sci. 2005;45:2557-62.

Riggins C.W. et al. Characterization of "de novo" transcriptome for waterhemp (Amaranthus tuberculatus) using GS-FLX 454 pyrosequencing and its application for studies of herbicide target-site genes. Pest Manag Sci. 2010;66:1042-52.

Rodrigues B.N., Almeida F.S. Guia de herbicidas. 6.ed. Londrina: 2011.

Rowland M.W. et al. Full-season Palmer amaranth (Amaranthus palmeri) interference with cotton (Gossipium hirsutum). Weed Sci. 1999;47:305-9.

Seefeldt S.S. et al. Log-logistic analysis of herbicide doseresponse relationship. Weed Technol. 1995;9:218-27.

Streibig J.C. Herbicide bioassay. Weed Res. 1988;28:479-84.

Ward S.M. et al. Palmer amaranth (Amaranthus palmeri): a review. Weed Technol. 2013;27:12-27.

Wassom J.J., Tranel P.J. Amplified fragment length polymorphism-based genetic relationships among weedy Amaranthus species. J Hered. 2005;96:410-6.

Wise A.M. et al. Establishing the geographical distribution and level of acetolactate synthase resistance of palmer amaranth (Amaranthus palmeri) accessions in Georgia. Weed Technol. 2009;23:214-20.

Planta Daninha, Viçosa-MG, v. 34, n. 3, p. 581-587, 2016 